\title{
HUBUNGAN KONDISI FASILITAS PEDESTRIAN TERHADAP ASPEK KESELAMATAN PEJALAN KAKI DI DEPAN LIPPO PLAZA KOTA KENDARI
}

\author{
La Ode Sarmin ${ }^{1}$, La Ode Muh. Magribi ${ }^{2}$, dan Sunaryo ${ }^{3)}$ \\ ${ }^{1}$ Mahasiswa Teknik Sipil, Fakultas Teknik, Universitas Sulawesi Tenggara \\ email: Sarminlaode@gmail.com \\ ${ }^{2}$ Dosen, Jurusan Teknik Sipil,Fakultas Teknik, Universitas Sulawesi Tenggara \\ email: obimagribi@yahoo.com \\ ${ }^{3}$ Dosen, Jurusan Teknik Sipil,Fakultas Teknik, Universitas Sulawesi Tenggara \\ email: sunaryocim@gmail.com
}

\begin{abstract}
This study aims to determine the characteristics of pedestrians, the existing conditions of pedestrian facilities, aspects of pedestrian safety, and the relationship of conditions of pedestrian facilities to aspects of pedestrian safety in front of the Lippo Plaza Kendari City. Technical data analysis using mathematical equations and non parametric statistical analysis with the help of SPSS 21.The results showed that the characteristics of the foot in front of the Lippo Plaza Kendari Cityfrom the calculation results obtained by the pedestrian flow $(Q)$ in segment 1 at 16:00 to 21:00 at 1,61 people/meter/minute while in segment 2 at 1,56 people/meter/minute, the average speed of the pedestrian room (Vs) is 61,35 meters/minute, pedestrian density (D) is 0,026 people/meter, pedestrian space $(S)$ is 38,72 meters ${ }^{2} /$ person. The existing condition of the pedestrian facility in front of the Lippo Plaza Kendari City was included in the criteria that is not good that is equal to 39,3\% while the safety aspects included in the criteria are not good at $46 \%$. There is a relationship between the condition of pedestrian facilities and aspects of pedestrian safety but is very weak with a value of 0,139
\end{abstract}

Keywords : Characteristics, Conditions, and Pedestrian Safety.

\begin{abstract}
ABSTRAK
Penelitian ini bertujuan untuk mengetahui karakteristik pejalan kaki, kondisi eksisting fasilitas pedestrian, aspek keselamatan pejalan kaki, dan hubungan kondisi fasilitas pedestrian terhadap aspek keselamatan pejalan kaki di depan Lippo Plaza Kota Kendari. Teknis analisis data menggunakan persamaan matematis dan analisis statistik non parametrik dengan bantuan SPSS 21. Hasil penelitian menunjukkan bahwa karakteristik pejalalan kaki di depan Lippo Plaza Kota Kendari dari hasil perhitungan diperoleh arus pedestrian $(Q)$ di segmen 1 pada pukul 16:00-21:00 sebesar 1,61 orang/meter/menit sedangkan pada segmen 2 sebesar 1,56 orang/meter/menit, kecepatan rata-rata ruang pedestrian (Vs) sebesar 61,35 meter/menit, kepadatan pedestrian (D) sebesar 0,026 orang/meter, ruang pedestrian (S) sebesar 38,72 meter ${ }^{2}$ orang. Kondisi eksisting fasilitas pedestrian di depan Lippo Plaza Kota Kendari masuk dalam kriteria tidak baik yaitu sebesar 39,3\% sedangkan aspek keselamatan masuk dalam kriteria tidak baik yaitu sebesar $46 \%$. Ada hubungan antara kondisi fasilitas pedestrian dengan aspek keselamatan pejalan kaki namun sangat lemah dengan nilai sebesar 0,139.
\end{abstract}

Kata Kunci: Karakteristik, Kondisi, dan Keselamatan Pejalan Kaki

\section{PENDAHULUAN}

Di Indonesia, pejalan kaki merupakan pelaku perjalanan yang paling rentan terhadap kecelakan. Pejalan kaki banyak berjalan di tepi jalan dan menyeberang di sembarang tempat sepanjang ruas jalan.
Penyediaan fasilitas pejalan kaki harus dapat memenuhi kebutuhan masyarakat yang menggunakannya. Fasilitas pejalan kaki harus dapat memenuhi kebutuhan berdasarkan aspek kenyamanan, keselamatan, dan keamanan pejalan kaki sebagai penggunanya (Murthy 2013, 
Dalam Mayona 2015). Kota Kendari merupakan Ibu Kota Sulawesi Tenggara, yang sedang berkembang pesat, baik dari tingkat perekonomian maupun jumlah penduduknya. Hal itu terlihat dari banyaknya kawasan-kawasan pusat perbelanjaan dan salah satunya yang dimaksud adalah Lippo Plaza Kota Kendari, yang menarik banyak perhatian masyarakat penduduk Kota Kendari untuk berkunjung, sehingga jumlah pengunjungnya sangat tinggi. Kegiatan ekonomi yang berada pada kawasan Lippo Plaza Kendari dapat mengundang pelakupelaku aktivitas di ruang publik yang memanfaatkan fasilitas pejalan kaki. Ditemukan beberapa permasalahan yang terjadi di kawasan pusat perbelanjaan Lippo Plaza Kendari di antaranya Banyaknya kendaraan parkir di badan jalan sehingga menganggu akifitas pelajan kaki, Banyaknya jumlah volume pejalan kaki, sehingga dimensi fasilitas pedestrian (trotoar dan zebra cross) tidak bisa menampung aktifitas pejalan kaki. Banyaknya pejalan kaki berjumlah 20 sampai 50 orang pejalan kaki dalam 15 menit, Masih kurangnya fasilitas-fasiliats pedestrian yang menunjang keselamatan pejalan kaki. Misalnya zebra cross tidak berfungi dengan baik (garis-garis tanda zebra cross tidak ada), lapisan permukaan trotoar sebagian rusak, lampu penerangan masih kurang, trotoar di seberang jalan depan Lippo Plaza tidak ada, halte tidak tersedia, dan bangku-bangku tempat istirahat tidak tersedia. Berdasarkan uraian tersebut maka penelitian ini bertujuan untuk mengetahui karakteristik pejalan kaki di depan Lippo Plaza Kota Kendari, mengetahui kondisi eksisting fasilitas pedestrian di depan Lippo Plaza Kota Kendari, menganalisis aspek keselamatan pejalan kaki di depan Lippo Plaza Kota Kendari, menganalisis hubungan kondisi fasilitas pedestrian terhadap aspek keselamatan pejalan kaki.

\section{TINJAUAN PUSTAKA}

Pedestrian berasal dari bahasa Yunani, dimana berasal dari kata pedos yang berarti kaki, sehingga pedestrian dapat diartikan sebagai kaki, sedangkan jalan merupakan media di atas bumi yang memudahkan manusia dalam tujuan berjalan, maka pedestrian memiliki arti pergerakan atau perpindahan orang atau manusia dari satu tempat sebagai titik tolak ke tempat lain sebagai tujuan dengan menggunakan moda jalan kaki. Atau secara harfiah, pedestrian berarti " person walking in the street", yang berarti orang yang berjalan di jalan (Rahman, 2014).

Fasilitas Pejalan kaki dapat dipasang dengan kriteria sebagai berikut, (Direktorat Jendral Bina Marga, 1995):

1) Pada lokasi-lokasi dimana pemasangan fasilitas tersebut memberikan manfaat yang maksimal, baik dari segi keamanan, kenyamanan ataupun kelancaran perjalanan bagi pemakainya.

2) Pada lokasi-lokasi/kawasan yang terdapat sarana dan prasarana umum.

3) Di sepanjang jalan atau pada suatu kawasan yang akan mengakibatkan pertumbuhan pejalan kaki dan biasanya diikuti oleh peningkatan arus lalu lintas serta memenuhi syaratsyarat atau ketentuan-ketentuan untuk pembuatan fasilitas tersebut.

Menurut Keputusan Ditjen Bina Marga tentang Pedoman Perencanaan Jalur Pejalan Kaki pada Jalan Umum (1999):

1) Trotoar Trotoar merupakan jalur pejalan kaki yang terletak pada daerah milik jalan yang diberi lapisan permukaan dengan elevasi yang lebih tinggi dari permukaan perkerasan jalan, dan pada umumnya sejajar dengan lalu lintas kendaraan.

2) Penyeberangan

a) Penyeberangan Sebidang

b) Penyeberangan Tak Sebidang 
Menurut Ashadi ddk (2011) Elemenelemen jalur pedestrian diperlukan pendekatan secara optimal terhadap lokasi dimana jalur pedestrian tersebut berada. Elemen pada suatu jalur pedestrian dapat dibedakan menjadi dua yaitu :

1) Elemen jalur pedestrian sendiri (material dari jalur pedestrian), dan. elemen pendukung pada jalur pedestrian (lampu penerang, vegetasi, tempat sampah, telepon umum, halte, tanda petunjuk dan lainnya).

2) Elemen pendukung pada jalur pedestrian (lampu penerang, vegetasi, tempat sampah, telepon umum, halte, tanda petunjuk dan lainnya).

Beberapa karakteristik pejalan kaki adalah sebagai berikut (Artawan dkk, 2013 dalam Mubarok, 2014) :

1) Arus

Arus pejalan kaki adalah jumlah pejalan kaki yang melintasi suatu titik pada penggal trotoar dan diukur dalam satuan pejalan kaki per meter per menit. Untuk menentukan arus digunakan persamaan sebagai berikut:

$\mathrm{Q}=\frac{N}{T}$

Keterangan:

$\mathrm{Q}=$ Arus pejalan kaki

(orang/m/menit)

$\mathrm{N}=$ Jumlah pejalan kaki yang lewat

per meter (orang/m)

$\mathrm{T}=$ Waktu pengamatan (menit)

2) Kecepatan

Kecepatan adalah jarak yang dapat ditempuh oleh pejalan kaki pada suatu ruas trotoar per satuan waktu tertentu. Untuk menentukan kecepatan digunakan persamaan sebagai berikut:

$\mathrm{V}=\frac{L}{t}$

Keterangan :

$\mathrm{V}=$ Kecepatan pejalan kaki (m/menit)

$\mathrm{L}=$ Panjang penggal pengamatan $(\mathrm{m})$

$\mathrm{t}=$ Waktu tempuh pejalan kaki yang melewati segmen

pengamatan (menit)

a) Kecepatan Rata-Rata Ruang (Vs)

$\mathrm{Vs}=\frac{1}{\frac{1}{n} \sum_{i=1}^{n} \frac{1}{V i}}$

Keterangan :

$\mathrm{Vs}=$ Kecepatan rata-rata ruang (m/menit)

$\mathrm{n}=$ Jumlah data

$\mathrm{Vi}=$ Kecepatan tiap pejalan kaki yang diamati (m/menit)

3) Kepadatan

Kepadatan adalah jumlah pejalan kaki persatuan luas trotoar tertentu. Untuk menentukan kepadatan digunakan persamaan sebagai berikut :

$\mathrm{D}=\frac{Q}{V s}$

Keterangan :

$\mathrm{D}=$ Kepadatan (orang $/ \mathrm{m})$

$\mathrm{Q}=$ Arus (orang $/ \mathrm{m} / \mathrm{menit}$ )

$\mathrm{Vs}=$ Kecepatan rata-rata ruang (m/menit)

4) Ruang Pejalan Kaki

Ruang pejalan kaki adalah luas area rata-rata yang tersedia untuk masingmasing pejalan kaki pada suatu trotoar yang dirumuskan dalam satuan $\mathrm{m}^{2}$ /orang:

$\mathrm{S}=\frac{V s}{Q}=\frac{1}{D}$

Keterangan :

$$
\begin{aligned}
\mathrm{S} & =\text { Ruang pejalan kaki }\left(\mathrm{m}^{2} /\right. \text { orang) } \\
\mathrm{D} & \left.=\text { Kepadatan (orang/m } \mathrm{m}^{2}\right) \\
\mathrm{Q} & =\text { Arus (orang/m/menit) } \\
\mathrm{Vs} & =\text { Kecepatan rata-rata ruang } \\
(\mathrm{m} / \mathrm{menit}) &
\end{aligned}
$$

\section{METODE PENELITIAN}

- Lokasi Penelitian

Penelitian ini berlokasi di ruas Jalan M.T. Haryono, studi kasus depan kawasan pusat perbelanjaan Lippo Plaza Kota Kendari, sepanjang 125 meter pengamatan.Kawasan tersebut merupakan salah satu pusat perekonomian/perbelanjaan yang menunjang kebutuhan manusia, ruas 
jalan tersebut merupakan sistem jaringan jalan dengan peranan pelayanan jasa distribusi.

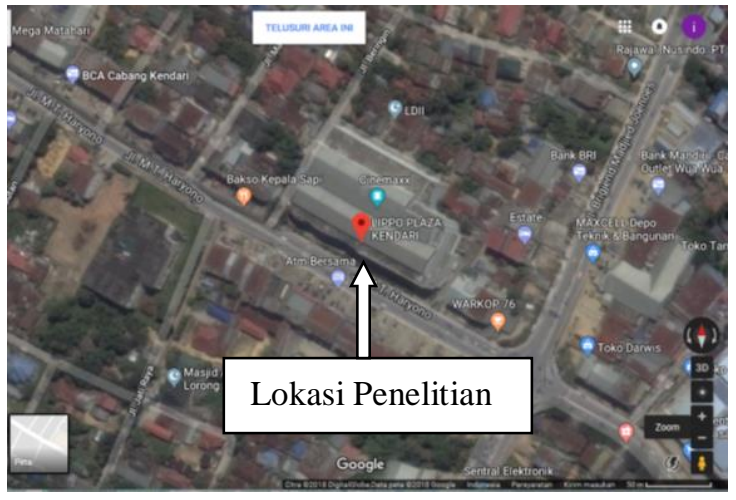

Gambar 1 Lokasi Penelitian

\section{- Teknik Pengumpulan Data}

Survei observasi langsung dilakukan pada hari minggu 30 Desember 2018. Survei tersebut dilakukan sehari mulai pukul 16:00-21:00 wita. Dipilih pada waktu tersebut karena berdasarkan observasi awal pada jam-jam tersebut jumlah pejalan kaki di depan Lippo Plaza Kota Kendari cukup padat.

Langkah-langkah pengambilan data ini adalah sebagai berikut :

1) Data jumlah pejalan kaki

a) Menentukan daerah pengamatan, untuk mempermudah perhitungan volume pejalan kaki maka perlu dibagi dalam beberapa segmen baik untuk pejalan kaki di trotoar maupun penyeberang jalan di zebra cross.

b) Untuk pengguna trotoar dibagi dalam dua segmen yaitu segmen 1 (sisi kanan Lippo Plaza baik yang menuju maupun keluar Lippo Plaza) sepanjang $25 \mathrm{~m}$, sedangkan segmen 2 (sisi kiri Lippo Plaza baik yang menuju maupun keluar Lippo Plaza) sepanjang $100 \mathrm{~m}$.

c) Untuk zebra cross terbagi dalam dua segmen yaitu segmen 1 (dari depan pintu masuk/keluar Lippo Plaza Kota Kendari menyeberang ke seberang jalan), sedangkan segmen 2 ( dari seberang jalan menyeberang ke depan pintu masuk/keluar Lippo Plaza Kota Kendari.

d) Setiap pejalan kaki yang melalui daerah yang telah ditentukan tersebut dihitung kemudian dicatat dalam form survei.

e) Hitungan dilakukan dalam interval 15 menit selama waktu yang telah ditentukan sebelumnya yaitu dari pukul 16:00-16:15 wita dan seterusnya sampai pukul 21:00 wita.

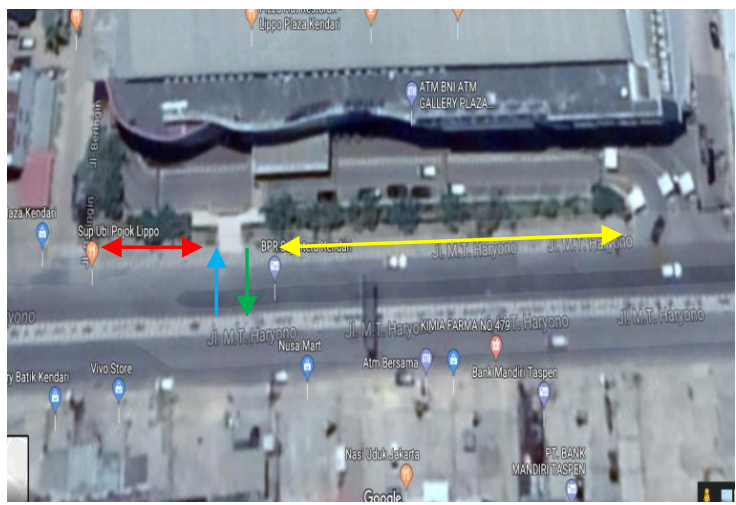

Gambar 2 Segmen Pengamatan Pejalan Kaki

Keterangan :

$\longleftrightarrow=$ Segmen 1 pengguna trotoar yang menuju dan keluar Lippo Plaza panjang pengamatan $25 \mathrm{~m}$ (sisi kanan Lippo Plaza).

$\leftrightarrow=$ Segmen 2 pengguna trotoar yang menuju dan keluar Lippo Plaza panjang pengamatan $100 \mathrm{~m}$ (sisi kiri Lippo Plaza).

$\longrightarrow=$ Segmen 1 dari depan pintu masuk/keluar Lippo Plaza menyeberang ke seberang jalan.

$\longrightarrow=$ Segmen 2 dari seberang jalan menyeberang ke depan pintu masuk/keluar Lippo Plaza.

2) Data kecepatan pejalan kaki

a) Pengambilan sampel data kecepatan pejalan kaki hanya diambil pada pengguna trotoar.

b) Pada segmen satu dan dua dilakukan penandaan dua garis acu ( misalnya A dan B)

c) Ketika pejalan kaki berada pada titik A kita sudah mulai mengamati 
pejalan kaki tersebut menggunakan stopwatch dan ketika pejalan kaki tersebut berada pada titik B maka kita mengakhiri pengamatan tersebut sehingga diperoleh kecepatan pejalan kaki. Jumlah sampel yang diambil yaitu 10 sampel untuk masing-masing segmen yaitu segmen satu dan dua.

3) Data Volume Lalu Lintas

a) Menentukan daerah pengamatan, ada dua arah pengamatan volume lalu lintas yaitu dari arah Wua-Wua menuju Pasar Baru dan dari arah Pasar Baru menuju Wua-Wua.

b) Jenis kendaraan yang dihitung meliputi kendaraan sepeda motor, kendaraan ringan, dan kendaraan berat.

c) Setiap ada kendaraan yang lewat kemudian dihitung dan dicatat kedalam form survei yang telah dipersiapkan. Pengukuran ini dilakukan setiap 15 menit.

4) Kuesioner

Mengumpulkan data dengan mengirim pertanyaan untuk diisi sendiri oleh responden, dilakukan dengan menyebar form kuesioner yang berisi pertanyaanpertanyaan meliputi penilaian kualitas fasilitas pedestrian dan pengaruhnya pada aspek keselamatan pejalan kaki di kawasan Lippo Plaza Kota Kendari.

\section{HASIL DAN PEMBAHASAN}

\section{A.Karakteristik Pejalan Kaki (Pedestrian)}

Karakteristik pejalan kaki dianalilsis menggunakan persamaan matematis pada bab 2, hasil analisis tersebut disajikan dalam tabel berikut ini.

Tabel 1. Rekapitulasi Perhitungan Karakteristik Pejalan Kaki

\begin{tabular}{|c|c|c|c|c|c|c|}
\hline \multirow{3}{*}{ Arah } & \multicolumn{5}{|c|}{ Karakteristik Pejalan Kaki } \\
\cline { 2 - 6 } & Q trotoar & Q zebra cross & Vs & D & S & $\begin{array}{c}\text { Tingkat } \\
\text { Pelayanan }\end{array}$ \\
\cline { 2 - 6 } & $($ Org/m/mnt $)$ & $($ Org/m/mnt $)$ & $(\mathrm{m} / \mathrm{mnt})$ & $\left(\mathrm{Org} / \mathrm{m}^{2}\right)$ & $\left(\mathrm{m}^{2} / \mathrm{org}\right)$ & A \\
\hline Segmen 1 & 1,61 & 1,26 & 62,69 & 0,026 & 38,96 & A \\
\hline Segmen 2 & 1,56 & 1,08 & 60,01 & 0,026 & 38,47 & $\mathbf{A}$ \\
\hline Rata-rata & $\mathbf{1 , 5 8}$ & $\mathbf{1 , 1 7}$ & $\mathbf{6 1 , 3 5}$ & $\mathbf{0 , 0 2 6}$ & $\mathbf{3 8 , 7 2}$ & .
\end{tabular}

Sumber : Hasil Analisis Data 2019

Berdasarkan tabel 1 diketahui bahwa tingkat pelajanan pejalan kaki di depan Lippo Plaza berada di standar A. Hal ini dikarenakan ruang pejalan kaki di depan Lippo Plaza lebih besar dari $12 \mathrm{~m}^{2} /$ orang yaitu sebesar $38,96 \mathrm{~m}^{2} /$ orang. Artinya para pejalan kaki dapat berjalan dengan bebas, termasuk dapat menentukan arah berjalan dengan bebas, dengan kecepatan yang relatif cepat tanpa menimbulkan gangguan antara pejalan kaki.

Dalam penelitian ini peneliti tidak membahas volume lalu lintas secara detail. Berdasarkan hasil analisis diperoleh arus lalu lintas rata-rata di depan Lippo
Plaza Kota Kendari sebesar $\frac{1593+2161}{2}=$ $1877 \mathrm{kend} / \mathrm{jam}$ artinya lebih besar dari $500 \mathrm{kend} / \mathrm{jam}$, sedangkan jumlah pejalan kaki yang menyeberang rata-rata di atas 50 pejalan kaki/jam. Berdasarkan nilai arus lalu lintas pejalan kaki (P) dan arus lalu lintas kendaraan dua arah per jam (V) dapat disimpulkan dengan melihat tabel 2.4 bahwa jenis fasilitas penyeberangan $\left(\mathrm{PV}^{2}\right)$ sebesar $>10^{8}$ dengan rekomendasi menggunakan pelican Cross . Pelican cross adalah penyeberangan pejalan kaki yang dilengkapi dengan lampu lalu lintas untuk menyeberang jalan dengan aman dan nyaman. 


\section{B. Karakteristik Responden}

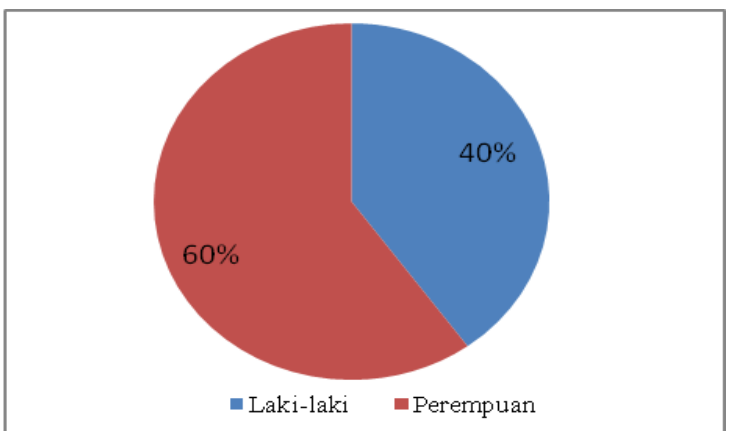

Gambar 3. Grafik Karakteristik Responden

Berdasarkan Jenis Kelamin

Sumber : Hasil Analisis Data 2019

Berdasarkan gambar 3 menunjukkan bahwa jumlah responden laki-laki sebanyak $40 \%$ atau 12 orang dan responden perempuan sebesar $60 \%$ atau 18 orang.

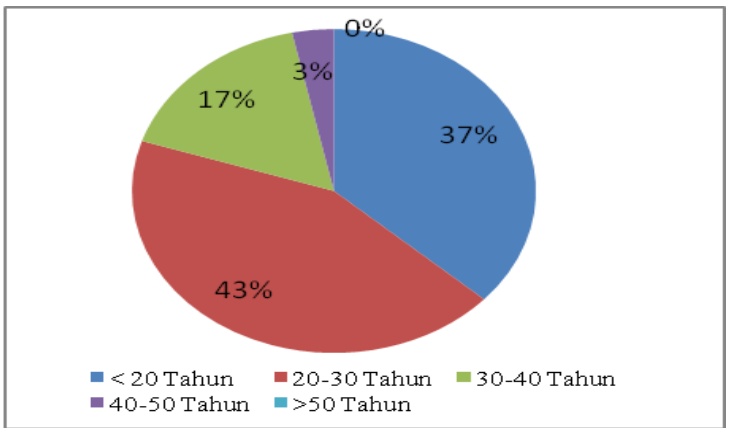

Gambar 4. Grafik Karakteristik Responden Berdasarkan Umur

Sumber : Hasil Analisis Data 2019

Berdasarkan gambar 4 menunjukkan bahwa jumlah responden yang berumur dibawah 20 tahun sebanyak $37 \%$ atau 11 orang, responden yang berumur 20-30 tahun sebesar $43 \%$ atau 13 orang, responden yang berumur 30-40 tahun sebesar $17 \%$ atau 5 orang, responden berumur 40-50 tahun sebesar $3 \%$ atau 1 orang, dan responden dengan umur diatas 50 tahun adalah 0 .

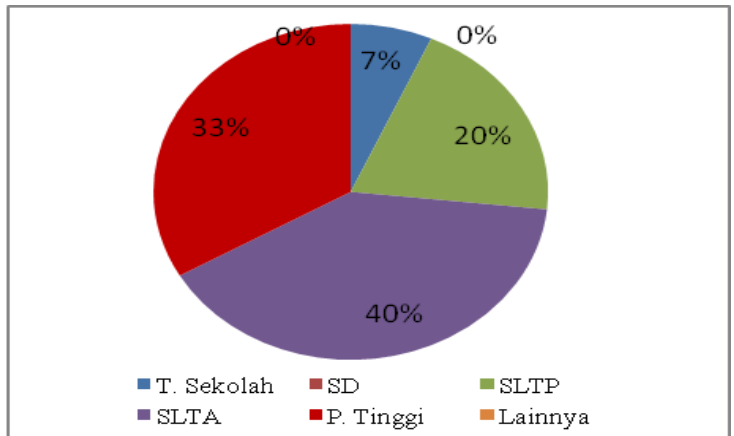

Gambar 5 Grafik Karakteristik Responden

Berdasarkan Pendidikan Terakhir

Sumber : Hasil Analisis Data 2019

Berdasarkan gambar 5 menunjukkan bahwa jumlah responden yang tidak sekolah sebesar $7 \%$ atau 2 orang, responden pendidikan terakhir SD sebesar $0 \%$, responden pendidikan terakhir SLTP sebesar $20 \%$ atau 6 orang, responden pendidikan terakhir SLTA sebesar $40 \%$ atau 12 orang, responden pendidikan terakhir perguruan tinggi sebesar $33 \%$ atau 10 orang, responden dengan kriteria lainnya sebesar $0 \%$.

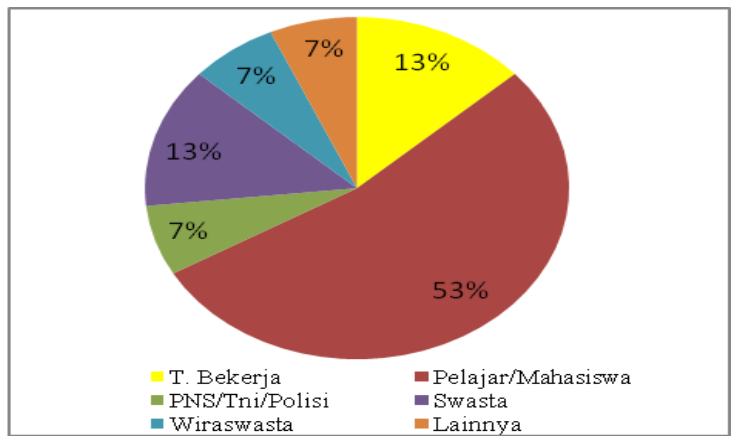

Gambar 6 Grafik Karakteristik Responden

Berdasarkan Pekerjaan

Sumber : Hasil Analisis Data 2019

Berdasarkan ganbar 6 menunjukkan bahwa jumlah responden yang tidak bekerja sebesar $13 \%$ atau 4 orang, responden yang sebagai pelajar/mahasiswa sebesar $53 \%$ atau 16 orang, responden yang bekerja sebagai PNS/TNI/Polisi sebesar $7 \%$ atau 2 orang, responden yang bekerja sebagai pegawai swasta sebesar 13 $\%$ atau 4 orang, responden yang bekerja sebagai wiraswasta sebesar $7 \%$ atau 2 orang, dan responden yang bekerja sebagai kriteria lainnya sebesar $7 \%$ atau 2 orang. 


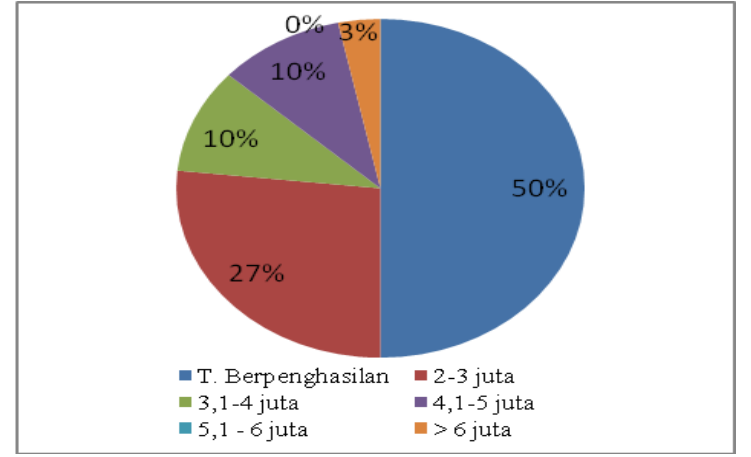

Gambar 7 Karakteristik Responden

Berdasarkan Penghasilan Perbulan

Sumber : Hasil Analisis Data 2019

Berdasarkan gambar 7 menunjukkan bahwa jumlah responden yang tidak berpenghasilan sebesar $50 \%$ atau 15 orang, responden yang berpenghasilan 2-3 juta sebesar $27 \%$ atau 8 orang, responden yang berpenghasilan 3,1-4 juta sebesar 10 $\%$ sebesar $10 \%$ atau 3 orang, responden yang 4,1-5 juta sebesar $10 \%$ atau 3 orang, responden yang berpenghasilan sebesar 5,1-6 juta sebesar 0\%, dan responden yang berpenghasilan diatas 6 juta sebesar $3 \%$ atau 1 orang.

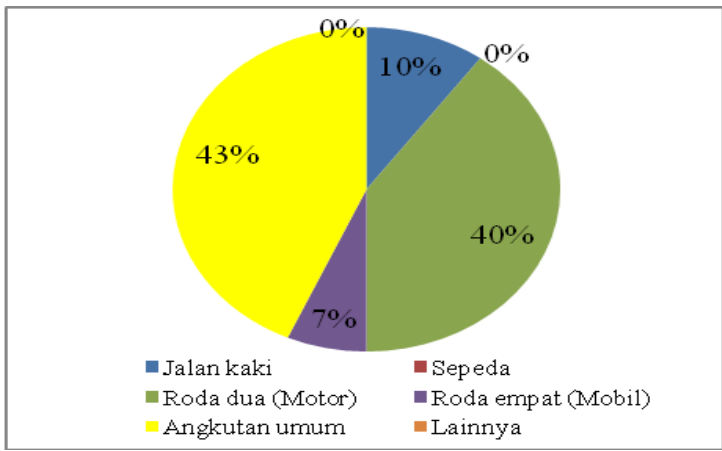

Gambar 8 Grafik Karakteristik Responden

Berdasarkan Moda Yang Digunakan

Sumber : Hasil Analisis Data 2019

Berdasarkan gambar 8 menunjukkan bahwa jumlah responden yang menggunakan moda jalan kaki sebesar 10 $\%$ atau 3 orang, responden yang menggunakan sepeda sebesar $0 \%$, responden yang menggunakan motor sebesar $40 \%$ atau 12 orang, reponden yang menggunakan mobil sebesar $7 \%$ atau 2 orang, responden yang menggunakan angkutan umum sebesar $43 \%$ atau 13 orang, dan responden yang menggunakan kriteria lainnya sebesar $0 \%$.

\section{Hasil Persepsi Responden}

1) Kondisi Fasilitas Pedestrian di Depan Lippo Plaza Kota Kendari Menurut Responden

Persepsi responden pejalan kaki mengenai kondisi fasilitas pedestrian di depan Lippo Plaza meliputi 10 faktor antara lain : penempatan trotoar, dimensi trotoar, lapisan permukaan trotoar, zebra cross, lampu penerangan, penempatan rambu, halte, tanaman peneduh, tampat sampah, bangku. Persepsi responden mengenai kondisi fasilitas pedestrian di depan Lippo Plaza dapat dilihat pada tabel berikut ini :

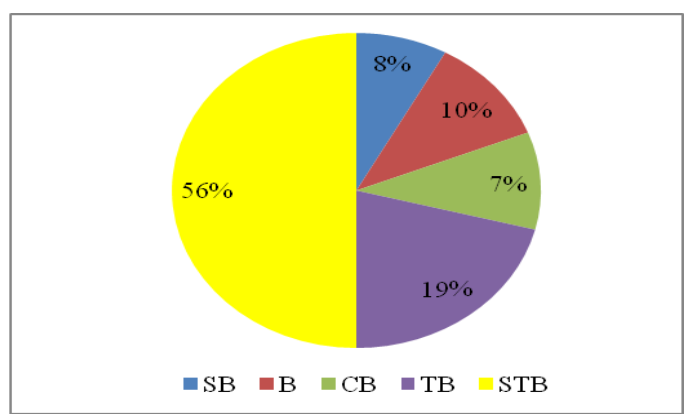

Gambar 9 Grafik Hasil Persepsi

Responden Terhadap Kondisi Fasilitas Pedestrian di Depan Lippo Plaza Sumber : Hasil Analisis Data 2019

Dari gambar 9 menunjukkan bahwa sebesar $8 \%$ responden menyatakan persepsi yang tergolong pada kriteria sangat baik, sebesar $10 \%$ responden menyatakan persepsi yang tergolong baik, sebesar $7 \%$ responden menyatakan persepsi yang tergolong cukup baik, sebesar $19 \%$ responden menyatakan persepsi yang tergolong tidak baik, dan sebesar $56 \%$ responden menyatakan persepsi yang tergolong sangat tidak baik. Dapat diketahui bahwa persepsi responden sangat tidak baik sangat mendominasi sebesar $56 \%$ sedangkan persepsi cukup baik sangat rendah sebesar $7 \%$. 
Tabel 2.Interval Kelas dan Kriteria Kondisi Fasilitas Pedestrian

$\begin{array}{ccc}\begin{array}{c}\text { Interval } \\ \text { Kelas (Skor) }\end{array} & \begin{array}{c}\text { Interval } \\ (\boldsymbol{\%})\end{array} & \text { Kriteria } \\ 1260-1500 & 84-100 & \text { Sangat Baik } \\ 1020-1260 & 68-84 & \text { Baik (B) } \\ 780-1020 & 52-68 & \text { Cukup Baik (CB) } \\ 540-780 & 36-52 & \text { Tidak Baik (TB) } \\ 300-540 & 20-36 & \text { Sangat Tidak Baik } \\ & & \text { (STB) }\end{array}$

Sumber : Hasil Analisis Data 2019

Berdasarkan tabel 2 diperoleh bahwa hasil perhitungan mengenai persepsi pejalan kaki tentang keselamatan yang ditinjau dari kondisi fasilitas pedestrian adalah menunjukkan angka 590 dan angka tersebut masuk dalam rentan interval skor 540 - 780, interval skor tersebut masuk dalam kriteria Tidak Baik (TB). Demikian juga interval presentase menunjukkan angka 39,3\% dan angka tersebut masuk dalam rentan interval presentase 36 - 52, interval presentase tersebut masuk dalam kriteria Tidak Baik (TB).
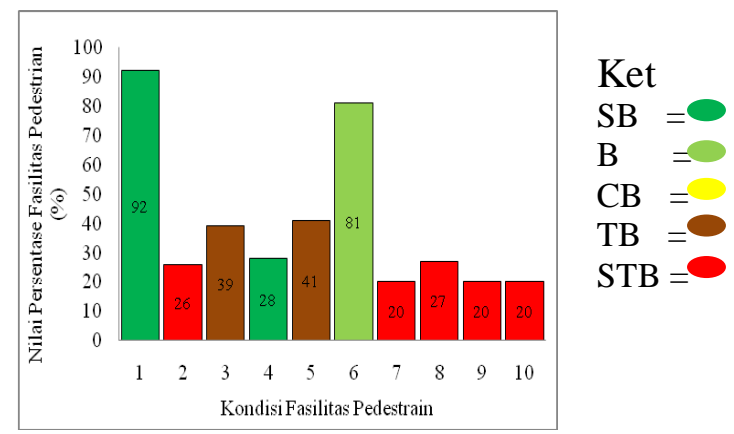

Gambar 10 Grafik Kondisi Masing-Masing Fasilitas Pedestrian di depan Lippo Plaza Sumber : Hasil Analisis Data 2019

Berdasarkan grafik 10 dapat diketahui bahwa kondisi fasilitas pedestrian yang mendapatkan nilai persepsi yang sangat baik yaitu penempatan trotoar sebesar 92\%. Sedangkan fasilitas pedestrian yang sangat tidak baik yaitu dimensi trotoar yang mendapakan nilai persepsi sebesar 26\%. Untuk halte, tempat sampah dan bangku mendapatkan persepsi sebesar $20 \%$ hal ini dikarenakan ketiga fasilitas tersebut tidak ada.

\section{2) Aspek Keselamatan Pejalan Kaki}

Persepsi pejalan kaki mengenai aspek keselamatan pejalan kaki di depan Lippo Plaza meliputi 9 faktor antara lain : kepedulian pengguna kendaraan bermotor terhadap kepentingan pejalan kaki, penghargaan terhadap penyeberang jalan khusus yang penyeberang di zebra croos, penghargaan bagi pejalan kaki oleh kendaraan parkir di badan jalan, trotoar seberang jalan lippo plaza, jalur pejalan kaki terpisah dari intervensi pengguna kendaraan, kepedulian pejalan kaki berjalan pada bagian jalan yang diperuntukan untuk pejalan kaki, kepedulian pejalan kaki yang merupakan penyandang cacat tuna netra wajib mempergunakan tanda-tanda khusus yang mudah dikenali pejalan kaki lainnya, kelengkapan fasilitas pejalan kaki, dan kepedulian pemerintah agar fasilitasfasilitas pejalan kaki mendapat perawatan sebagaimana mestinya.

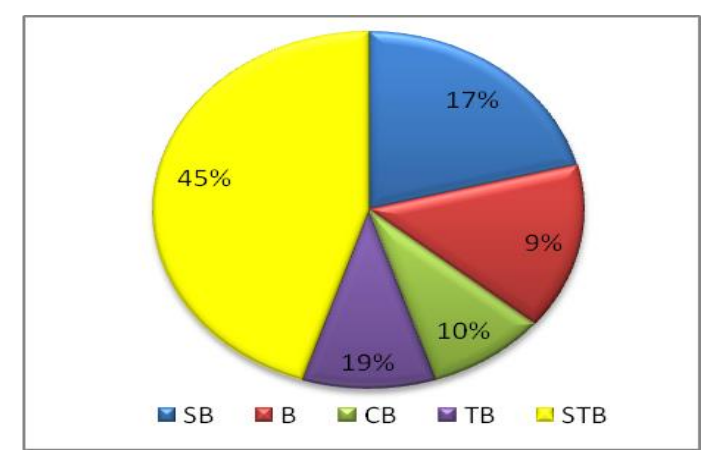

Gambar 11 Grafik Hasil Persepsi Responden Terhadap Aspek Keselamatan

Pejalan Kaki di Depan Lippo Plaza. Sumber : Hasil Analisis Data 2019

Dari gambar 11 menunjukkan bahwa sebesar $17 \%$ responden menyatakan persepsi yang tergolong pada kriteria sangat baik, sebesar $9 \%$ responden menyatakan persepsi yang tergolong baik, sebesar $10 \%$ responden menyatakan persepsi yang tergolong cukup baik, sebesar $19 \%$ responden menyatakan persepsi yang tergolong tidak baik, dan sebesar $45 \%$ responden menyatakan persepsi yang tergolong sangat tidak baik. 
Dapat diketahui bahwa persepsi responden sangat tidak baik sangat mendominasi sebesar $45 \%$ sedangkan persepsi baik sangat rendah sebesar $9 \%$.

Tabel 3. Interval Kelas dan Kriteria Aspek Keselamatan Pejalan Kaki

$\begin{array}{cc}\begin{array}{c}\text { Interval } \\ \text { Kelas } \\ \text { (Skor) }\end{array} & \begin{array}{c}\text { Interval } \\ (\boldsymbol{\%})\end{array} \\ 1134-1350 & 84-100 \\ 918-1134 & 68-84 \\ 702-918 & 52-68 \\ 486-702 & 36-52 \\ 270-486 & 20-36\end{array}$

Kriteria

Sangat Baik

Baik (B)

Cukup Baik (CB)

Tidak Baik (TB).

Sangat Tidak Baik (STB)

Sumber : Hasil Analisis Data 2019

Berdasarkan tabel 3 diperoleh bahwa hasil perhitungan mengenai persepsi pejalan kaki tentang keselamatan dan kenyamanan yang ditinjau dari tingkat keselamatan pejalan kaki adalah menunjukkan angka 623 dan angka tersebut masuk dalam rentan interval skor 486 - 702, interval skor tersebut masuk dalam kriteria Tidak Baik (TB). Demikian juga interval presentase menunjukkan angka $46 \%$ dan angka tersebut masuk dalam rentan interval presentase 36 - 52, interval presentase tersebut masuk dalam kriteria Tidak Baik (TB).

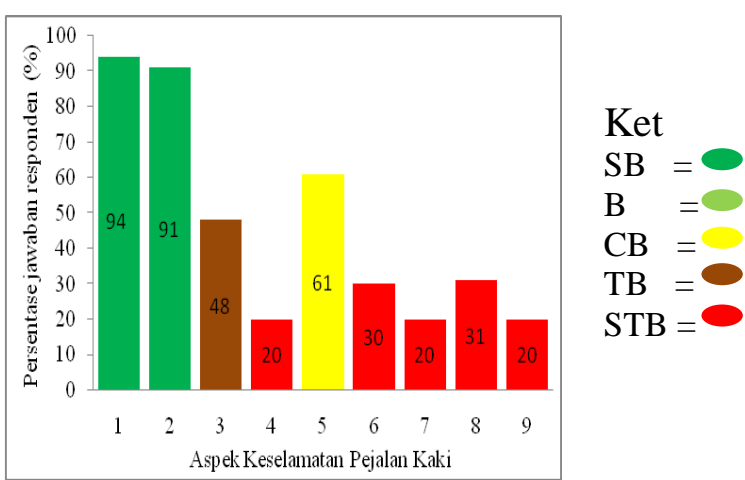

Gambar 12 Grafik Kondisi Masing-Masing Aspek Keselamatan Pejalan Kaki Sumber : Hasil Analisis Data 2019

Berdasarkan gambar 12 dapat diketahui bahwa aspek keselamatan pejalan kaki yang memperoleh nilai persepsi yang sangat baik yaitu kepedulian pengguna kendaraan bermotor terhadap kepentingan pejalan kaki yaitu sebesar 94\%. Hal tersebut ditandai dengan perilaku pengguna kendaraan yang mengontrol kecepatan kendaraan, mendahulukan kepentingan pejalan kaki, nyaman dan keselamatan tidak terganggu saat berjalan di trotoar. Sedangkan aspek keselamatan pejalan kaki yang sangat tidak baik yaitu trotoar di seberang jalan Lippo Plaza dan kepedulian pejalan kaki yang merupakan penyandang cacat cacat tuna netra wajib menggunakan tanda-tanda khusus yang mudah dikenali pejalan kaki lainnya masing-masing memiliki nilai persepsi sebesar $20 \%$. Hal tersebut akibatkan karena tidak tersedianya trotoar di seberang jalan di depan Lippo Plaza dan tidak terdapat jalur khusus bagi penyandang cacat tuna netra.

\section{Analisis Statistik Non Parametrik}

Tabel 4 Hasil Analisis Rank Spearman

Correlations

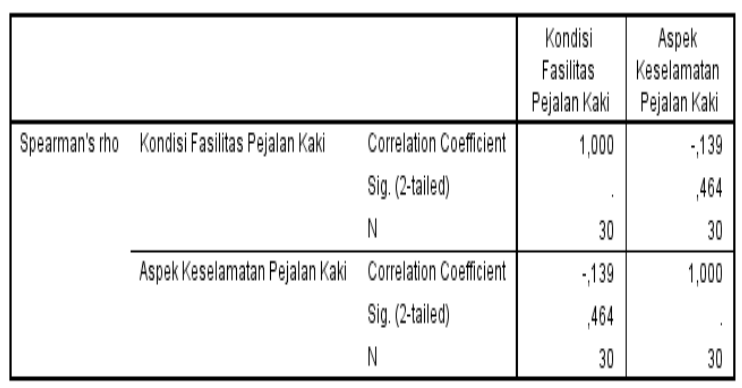

Sumber : Hasil Analisis Data 2019

Berdasarkan tabel 4 dapat dilihat bahwa berdasarkan output di atas, diketahui nilai signifikansi atau sig sebesar 0,464 , karena nilai sig $0,464>0,005$, maka artinya tidak ada hubungan yang signifikan (berarti) antara variabel kondisi fasilitas pejalan kaki terhadap aspek keselamatan pejalan kaki. Jika dilihat dari tingkat kekuatan (keeratan) hubungan, diperoleh angka koefisien korelasi sebesar 0,139, artinya tingkat kekuatan hubungan antara variabel kondisi fasilitas pejalan kaki terhadap tingkat keselamatan pejalan kaki 
adalah sebesar 0,139 atau sangat lemah. Jika dilihat dari arah (jenis) hubungan, angka koefisien korelasi pada hasil di atas, bernilai negatif, yaitu $-0,139$ artinya hubungan kedua variabel tersebut tidak searah. Dengan demikian, dapat disimpulkan bahwa $\mathrm{Ha}$ ditolak dan $\mathrm{Ho}$ diterima, artinya tidak ada hubungan yang signifikan antara kondisi pejalan kaki terhadap aspek keselamatan pejalan kaki.

\section{SIMPULAN DAN SARAN}

\section{A. Simpulan}

Dari hasil studi penelitian yang dilakukan di depan Lippo Plaza Kota Kendari, maka dapat diambil kesimpulan sebagai berikut :

1) Karakteristik pejalalan kaki di depan Lippo Plaza Kota Kendari diperoleh arus pedestrian (Q) di segmen 1 (sisi kanan Lippo Plaza) pada pukul 16:0021:00 sebesar $1,61 \quad \mathrm{org} / \mathrm{m} / \mathrm{mnt}$ sedangkan pada segmen 2 (sisi kiri Lippo Plaza) sebesar 1,56 org/m/mnt, kecepatan rata-rata ruang pedestrian (Vs) sebesar $61,35 \mathrm{~m} / \mathrm{mnt}$, kepadatan pedestrian sebesar $0,026 \mathrm{org} / \mathrm{m}$, ruang pedestrian sebesar $38,72 \mathrm{~m}^{2} / \mathrm{org}$.

2) Kondisi eksisting fasilitas pedestrian termasuk dalam kriteria tidak baik dimana nilai persen yang diperoleh dari hasil responden pedestrian sebesar 39,3 $\%$.

3) Tingkat keselamatan pejalan kaki termasuk dalam kriteria tidak baik dimana nilai persen yang diperoleh dari hasil responden pedestrian sebesar 46 $\%$.

4) Ada hubungan antara kondisi fasilitas pedestrian dengan aspek keselamatan pejalan kaki namun sangat lemah dengan nilai sebesar 0,139 .

\section{DAFTAR PUSTAKA}

Anonim. 1995. Departemen Pekerjaan Umum Direktorat Jendral Bina Marga, Tentang Tata Cara Perencanaan Fasilitas Pejalan Kaki di Kawasan Perkotaan.

Anonim. 1999. Keputusan Direktur Jendral Bina Marga, No. 76/ KPTS/Db. Tentang Pedoman Perencanaan Jalur Pejalan Kaki Pada Jalan Umum.

Ashadi, A. ddk, 2012. Analisa Pengaruh Elemen-Elemen Pelengkap Jalur Pedestrian Terhadap Kenyamanan Pejalan Kaki Studi Kasus Pedestrian Orchard Road, Singapura.

Mubarok, A.S. dan Sumabrata. J. 2014. Analisis Karakteristik Pejalan Kaki Di Plataran Stasiun Depok Baru". Jurnal. Teknik Sipil Universitas Indonesia Kampus Baru UI.

Murthy, Dalam Mayona, E, L. 2013. Identifikasi Kebutuhan Fasilitas Pejalan Kaki di Kota Pontianak.

Rahman, N. (2014) Studi Kenyamanan Jalur Pedestrian Pada Kawasan Water Front (Studi Kasus : Jalan Penghibur Dan Jalan Somba $\mathrm{Opu})$. 